\title{
Applying Maturity Framework to US Cinema for Analyzing the Commercial Culture Industry
}

\author{
Hyunjung Rhee ${ }^{1}$ \\ ${ }^{1}$ School of Cinematic Content, Dankook University, Gyeonggi, Korea \\ Correspondence: Hyunjung Rhee, School of Cinematic Content, Dankook University, Gyeonggi, Korea. Tel: \\ 82-10-8738-7725. E-mail: bonoanimi@gmail.com
}

Received: November 8, 2014

Accepted: December 31, 2014 Online Published: April 2, 2015

doi:10.5539/ass.v11n9p255

URL: http://dx.doi.org/10.5539/ass.v11n9p255

\begin{abstract}
In the $21^{\text {st }}$ century, the culture industry is being focused as the core growth engine of the future because of its high value added potentials. At such time, it is important to map out a proper plan for flourishing the culture industry depending on the current situation of each nation. However, there is a difficult point in evaluating the current culture itself in that it is abstruse due to its intangible value so that the necessity of analysis method development only for culture industry is emphasized. This paper is aimed to suggest a potential framework in order to estimate the quality of commercial culture within the framework of industry. For this purpose, we borrowed the concept of the maturity model, which has been generally applied for evaluating the quality of an intangible field. As a representative commercial culture, we chose the film industry for the analysis. We established a maturity framework for commercial culture based on a case study of the US cinema industrial history as a representative free economic system.
\end{abstract}

Keywords: commercial culture, experiential product evaluation, maturity framework, US cinema

\section{Introduction}

In the beginning of the $20^{\text {th }}$ century, "Culture Industry" has been first mentioned in the academic field by Adorno and Horkheimer (Kim et al., 2007). In accordance with the combination of those two differing words, 'culture' and 'industry', it is reasonable to assume that culture contains economic value. "Commercial cultures" (McAllister, 2003), such as blockbuster movies, TV shows and pop songs, becomes rather the prime mover creating added value in the $21^{\text {st }}$ world industry. Although culture itself cannot be judged by any standards, commercial culture is different; in capitalist society, culture is considerable in judging quality with various cultural products which are mostly experiential products. Then what would be estimated as a good commercial culture in the market? This question is important for both governments and enterprises in order to obtain ideas on how they can support and develop commercially worthwhile products, respectively.

The software industry, as well, plays a pivotal role in a nation's economic growth and is also crucial for evaluating the quality. Like cultural products, software is hard to evaluate before it has been experienced. The U S State Department, an institute to first adopt the software, has been supporting the SEI (Software Engineering Institute) at Carnegie Melon University in order to develop a measurable standard for the quality of software. As a result, the CMM (Capability Maturity Model) has been built, which is the first introduced the concept of "maturity." SMI insisted that "the quality of a product is largely determined by the quality of the process that is used to develop and maintain it" (Paulk et al., 1993). More specifically, the quality of software is possible to equate the quality of its producing environment.

Likewise, in this paper, maturity framework is presented as a method to figure out the quality level of commercial culture. the history of film is chosen as the source because; the film is one of the representative commercial cultures; in most nations, the film industry has begun at around the same period- the invention of technology; thus, the comparison between countries is easier; and about 100 years of film history is a proper length of time to observe clearly both industrial rises and falls. We especially chose US film history as the source for checking the possibility of applying maturity concept to see the quality of commercial culture of the period, because US film industry has been operating in a fully free-economic system from the very beginning. This paper suggests inferring the situation of commercial culture with the methodology of the case study of US cinema. 


\section{Definition and Method}

\subsection{Maturity Model}

The concept of "maturity" has first been suggested as a framework methodology in the CMM (Capability Maturity Model), which has been developed by SEI (Software Engineering Institute) at Carnegie Melon University, in 1984. The objective of the CMM is to establish a standard for evaluating the quality of software, upon the support of the U. S. government (Ramanujan \& Kesh, 2004). CMM represents the level of software depending on the quality of the developing process. Later, CMM has been developed into CMMI (Capacity Maturity Model Integration), an integration model suggesting global standards in order to improve process in a more efficient way for system-technology related enterprises.

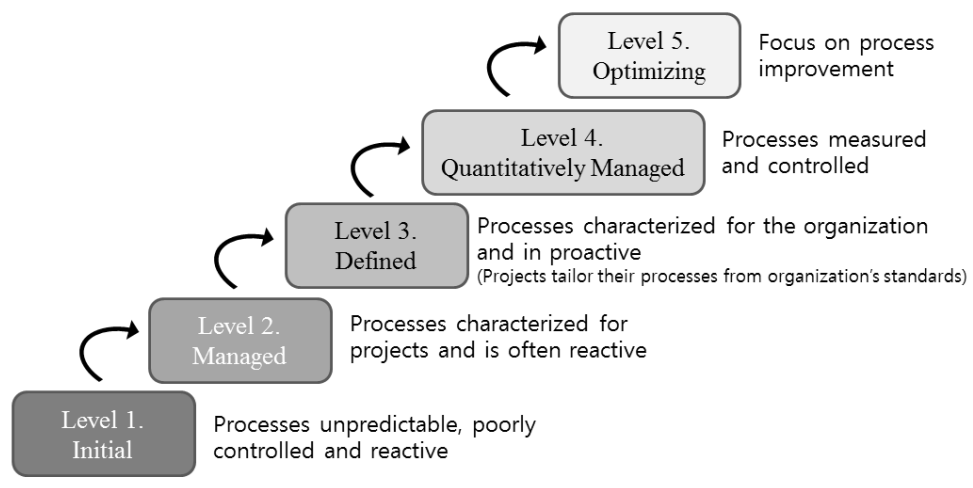

Figure 1. Characteristics of maturity levels

The concept of "maturity model" has been applied for evaluating the growth by comparing with that of others (Fisher, 2004; Harmon 2004; Spanyi, 2004). Later, it was applied for checking the capability levels of an organization in various fields, including business management, marketing, people capability, green environment, and so on (Ahern et al., 2004; Hakes, 1996; De Bruin et al., 2005); the characteristics of each level is shown as Figure 1. The EA (Enterprises Architecture) maturity model, which has a concept that is used worldwide and has also been developing properly depending on nations and periods, is one of the good maturity model examples for evaluating an organization's job performance. It has developed an objective to evaluate the strengths and weaknesses in each department through the whole analysis of organizational culture, capability, sources, and structures for all EA build-up object departments, such as the US Government Accountability Office, Department of Commerce and Office of Personnel Management.

Table 1. Maturity stage titles of different maturity models

\begin{tabular}{|c|c|c|c|c|c|c|c|}
\hline $\begin{array}{l}\text { Model Title } \\
\text { (Institution) }\end{array}$ & Level 0 & Level 1 & Level 2 & Level 3 & Level 4 & Level 5 & Level 6 \\
\hline $\begin{array}{c}\text { Capacity } \\
\text { Maturity Model } \\
\text { Integrated (SEI) }\end{array}$ & - & Initial & Managed & Defined & $\begin{array}{c}\text { Quantitatively } \\
\text { Managed }\end{array}$ & Optimizing & - \\
\hline $\begin{array}{c}\text { Business Process } \\
\text { Maturity Model } \\
\text { (Gartner) }\end{array}$ & - & $\begin{array}{c}\text { Process- } \\
\text { Aware }\end{array}$ & $\begin{array}{c}\text { Coordinated } \\
\text { Processes }\end{array}$ & $\begin{array}{c}\text { Cross- } \\
\text { Boundary } \\
\text { Process Mgmt }\end{array}$ & $\begin{array}{c}\text { Goal-Driven } \\
\text { Processes }\end{array}$ & $\begin{array}{l}\text { Optimized } \\
\text { Processes }\end{array}$ & - \\
\hline $\begin{array}{c}\text { Enterprise } \\
\text { Architecture } \\
\text { (US Gov) }\end{array}$ & $\begin{array}{l}\text { Create EA } \\
\text { Awareness }\end{array}$ & $\begin{array}{c}\text { Establish } \\
\text { Commitment } \\
\text { and direction }\end{array}$ & $\begin{array}{c}\text { Create a } \\
\text { management } \\
\text { foundation }\end{array}$ & $\begin{array}{c}\text { Develop } \\
\text { initial EA } \\
\text { versions }\end{array}$ & $\begin{array}{l}\text { Using EA for } \\
\text { targeted } \\
\text { results }\end{array}$ & $\begin{array}{l}\text { Use EA for } \\
\text { transformation }\end{array}$ & $\begin{array}{l}\text { Continuous } \\
\text { improvement }\end{array}$ \\
\hline $\begin{array}{l}\text { Business Maturity } \\
\text { model (Deloitte) }\end{array}$ & - & $\begin{array}{c}\text { Pioneer } \\
\text { Level }\end{array}$ & Process Level & $\begin{array}{l}\text { System } \\
\text { Level }\end{array}$ & $\begin{array}{c}\text { Network } \\
\text { Level }\end{array}$ & - & - \\
\hline $\begin{array}{c}\text { Technical } \\
\text { Capabilities } \\
\text { (AT Kearney) }\end{array}$ & - & Beginner & Reviewer & Overseer & Performer & Innovator & - \\
\hline $\begin{array}{l}\text { Green IT } \\
\text { (Accenture) }\end{array}$ & Incomplete & Initial & Repeatable & Defined & Managed & Optimized & - \\
\hline
\end{tabular}


As presented in Table 1, most of maturity models have adopted 5 levels. Each level is defined by the major processes associated with it. The lowest level commonly shows the barren environment of new starting processes or organizations. The second level, maturity models use the processing quality words such as 'coordinated', 'management foundation', and 'repeatable'; this represent that level 2 is the level of putting more effort is necessary. Level 3 seems to contain more manageable quality than level 2 and in level 4, the process eventually reach the point of become stable. The highest level shows optimizing and innovation process preparing for the future.

\subsection{Definition of 'Maturity' in Commercial Culture}

Previously, software quality-related maturity models are objective to minimize the rate of failure such that the indicators of each level are compromised by the quality of its developing environment and process. Organization competence evaluation models, such as the EA maturity model (Valdés, 2011), set each level with the quality of the operating system quality in institutions. As it is possible to guess from the examples of various maturity models, maturity models are particularly practical to the fields that are vague to evaluate with their intangible characteristics. Those models, first of all, set the objective (e.g., minimize rate of failure when determining the software purchase), find the information necessary in order to check meeting the objective (e.g., quality of software), and then determine the indicators based on the environment in which the information could come out from (e.g., the whole process until the software is made).

Likewise, we first set the objective in order to develop the maturity framework. We then diagnose the current commercial culture industry in countries and suggest possible strategic plans for the steps forward. In other words, in this paper, the concept of 'maturity' is in a completely economic perspective, meaning "widely acceptable enough to satisfy the diversity of great mass and widen the size of market." Thus, this framework can be considered as an indicating current standard of a nation's culture industry.

\subsection{Applying the Concept of Maturity Framework into Culture Industry}

As mentioned above, it is hardly acceptable to evaluate the quality of certain nation's culture. Ambiguous words, such as 'high-class culture' or 'savage culture', are used for class with power in the past in order to stress their superiority; hence, we should not be confused with the quality of the culture itself. This paper suggests a framework in order to see the commercializing value, and not the quality of culture. For such purpose, we first check the separate period from film history literatures, and then analyze each period based on economic growth and technological improvement. This framework establishes the foundation for building an actual maturity model in commercial culture.

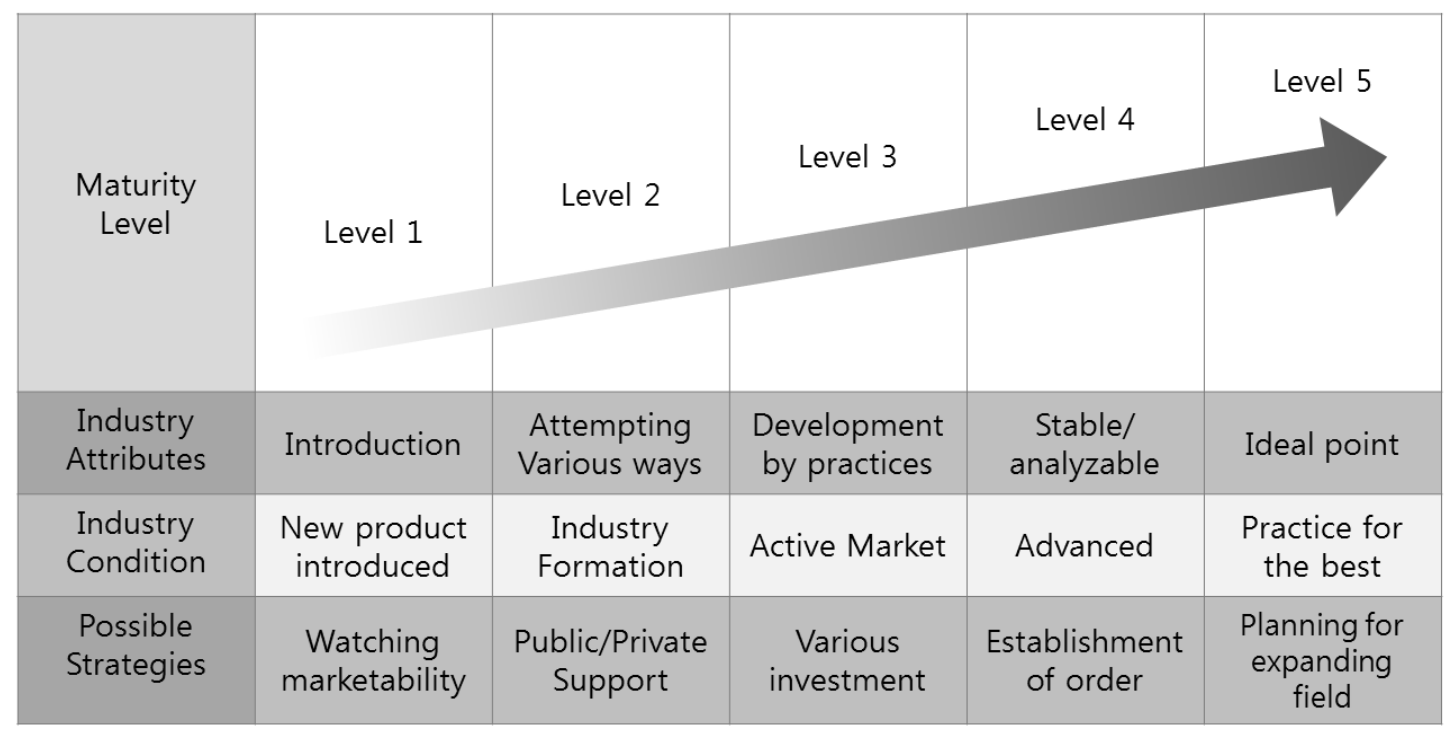

Figure 2. Suggested maturity framework outline

In accordance with the previous maturity model examples, the suggested maturity framework for commercial culture could be considered in order to construct Figure 2. 'Level 1' would certainly be the introductory period; the formative movement to the industry would be shown at this level. 'Level 2' can be considered as structuring the shape of the industry period. At this level, the market is not yet very competitive, but the nation actively 
supports looking further into the future. 'Level 3' can be the market boosting period by the number of enterprises rather than the national level. The industry condition would become pretty stable in 'Level 4'; the current lead in market could be considered at this level. Finally, in 'Level 5', "perfect monopoly" could be suggested as the ideal form for the lead in a market (Nightingale, 1978).

To provide the useful guidelines, the commercial culture maturity framework will provide both political and practical features of conditions and strategies at each level. Because the purpose of this study is to develop an industrial maturity framework, we suggest a possible direction rather than proposing specific evaluation standards similar to most maturity models.

\section{Maturity Concept Based Analysis of US Cinema History}

\subsection{Introduction Level: 1890s - 1910s}

During the introduction period, especially for commercial culture business, it was mostly important to have financial strength of the nation as well as to ensure the freedom of creation. In the case where there was demand but self-sufficiency was not possible, a country's reliance on foreign products was very high. During this level of period, the industry ecosystem was not yet constructed and therefore, the financial situation was easy to be in disequilibrium. Productions more focused on seizing a new market rather than caring about the quality of their commercial culture products.

The global film industry was centered on Europe in the beginning of the $20^{\text {th }}$ century. However, as a result of World Warl, that of the US took the lead. While all European nations were in chaos by the war, the US film market supply was able to satisfy the demand through domestic products. During this period, the number of theaters and audiences increased explicitly; hence, the US film industry went under a mass production system. At that Time, the center of the US film industry was New York; however, the area had a downside with its unstable climate to produce a numbers of films over a short-term period. Hence, film producing companies turned their attention to California, which has a warm and pretty stable climate, beautiful landscapes and rich human resources; gradually, the center of the industry moved to Hollywood (Thomson \& Bordwell, 2009).

\subsection{Industry Formation Level: 1920 s \& 1950s 1960s}

'Industry formation level' represents the period of the industry making various attempts in order to structure a stable market. It is the very next level of introduction in which most of the new industries are supposed to be. If the industry is not new, but stays in this level, the industry would be unstable from various effects, including external circumstance changes. Thus, the industry would attempt different strategies in order to find a proper structure for the currently paced circumstance. In US film history, we set two different periods into this level- in 1920s and 1960s.

From the late 1910s, production and distribution became integrated, as the so-called "studio system" was advent. In the late 1920s, only 5 major studios known as "The Big Five" and 3 minors known as "The Little Three," dominated the entire US film market. These studios built a very high entry barrier, making it difficult for new studios to enter the market. The development of film sound recording techniques and the birth of film festivals, such as the "Academy Awards," helped raise the status of the US film industry (Shin, 2013).

When the alternative media, television emerged in 1960s, the film market economy shrank. The spread of TVs in households was effective, strongly enough to change people's lifestyle; hence, the US cinema met its recession. In order to get out of the crisis, distinctive strategies were implemented; cinemas widened the screen size, positively adopted color film and improved the quality of sound (Thomson \& Bordwell, 2009). The Paramount Decrees closed its studio system. Major studios had a hard time and ultimately closed; however, mini-major, minor and independent film studios grew fast finding a way to coexist with the TV industry. From the late 1960s, in order to lower risks, Hollywood film studios made great effort to find "guaranteed" filmmakers. Great named directors have produced masterpieces in this period and also made great success in theaters. In fact, behind this success, new storytelling methods, which have been developed in the $1950 \mathrm{~s}$ and $60 \mathrm{~s}$, have been a great force (Thomson \& Bordwell, 2009).

Even though we put the $50 \mathrm{~s}$ to $60 \mathrm{~s}$ in the development level, this period differs from the period before the golden age in how the government treated the studios as well as how the studios reacted to the environmental influences. As a result, they attempted more various types of movies and became more enthusiastic in lowering risks on movie investments. The advent of a strong alternative media, TV, was eventually a cause to reconstruct the entire industry's rules in both cases. To handle this kind of crisis and to take a step forward, it is important to find a way to compete but also to cooperate, so that they attempted differentiation strategies in screen size, color and sound quality as a competitive way. The US government pushed a reconstruction policy against monopolization, 
and helped minor studios find a way to survive by cooperating with the TV, making image materials for broadcast so that they later could widen their position in the commercial culture industry. Although many of the major studios were falling apart, the reconstruction eventually vitalized the film industry.

\subsection{Market Boosting Level: 1930s 1940s \& 1980s}

At this level of period, film business is recognized as a very popular market, enough to create even added value. Similar with manufacturing business, the capital strength of major companies is very important in the commercial culture industry. Because building a high entry barrier also means that a great amount of capital was invested to the production, this could seem positive in the industry constructing period; right after the 'Industry formation' periods, which are after $20 \mathrm{~s}$ and after $60 \mathrm{~s}$, would represent this level.

From the early 1930s, until Paramount decrees have acted in 1949, Hollywood operated under a studio system; many of the major studios owned theaters in order to take all the profit earnings from their products. Further, they unified the whole production, distribution and show in theater processes. Although the depression in 1929 hit the economy of theaters, the film business was not very bad compared to other businesses. They covered their loss by lowering ticket prices and production cost. They produced huge amount of B-movies similar with prior successful examples; this became an opportunity to develop "the Hollywood Narrative Rules (Song, 2007)." Color film was developed during this period; yet, it did not appeal movie productions because there were no strong demands for color movies.

In the 1980s, even media or electronic domestic and multinational enterprises ran into the entertainment business through M\&A. They preoccupied windows for additional profit, such as video, cable TV and satellite TV after movie release. To give prominence to the "watching at theater value," many of those companies have attempted to produce movies in huge scale. The appearance of multiplex theaters and super blockbuster movies raised theater earnings.

\subsection{Stable Industry Level: 1990s Present}

The commercial culture industry in this level is authorized in the world market, such that the distribution between countries is very active. In the case of film business, not only the final product itself but also the staff, distribution rights and publication rights, are subject to deals. The government also acknowledges the commercial culture field as a value added industry. Audiences' attitude toward movies has become much mature; they recognize the value of watching in theaters and are not much agitated by the movie ticket price. Yet, the audiences are not mature enough in the current trend with fast developing technologies. Commercial culture in this level, with its intangibleness, ensures various windows for selling; thus, it is most important to protect products from illegal spreading.

In the mid-1990s, the regulation with regard to film studios owning a broadcasting station was mitigated, and media companies have become possible to operate networks and production studios. Dreamworks, one of those multi-operational companies, emerged in this period, and invested intensively in multimedia. With the big success of 'Twister' (1996), film productions even believed that special effects can cover the absence of narratives (Seo, 2009). This idea carried out continuous failure of big budget blockbusters. On the other hand, it strengthened the competitiveness of computer graphics technology for films. As a result, special effects and animation technology have made remarkable development in the 1990s. Blockbusters mostly have been venturing into wide-release with the strategy of huge box-office in the opening weeks so that film productions increased the budget for promotion and marketing.

In the 2000s, vertical integration has been leading under IT and communication companies. This aspect seems to have been engendered from the advent of convergence culture (Jenkins, 2008). Theaters have renovated facilities and raised the average ticket price; however, it did not have much effect on the number of audience; audiences have become mature enough to realize the value of watching in theaters. Until now, film productions, in order to reduce risks, have been creating sequels to hit movies and numerous series based on famous comics or novels.

Commercial culture productions have the know-how of which elements appeal to the targeted audiences in some degree. They collect information based on past records and also establish somehow the grammar or rules for success. Yet, because the taste of people and trends continue to change, production companies at this level tend to high marketing costs.

\subsection{Toward Dominating the Entire Global Market Level}

This level describes the ideal form of industry. Nightingale (1978), in his research for defining the meaning of industry and market, gathered two different scholars' opinions; he reached that 'market' is with "a distinctive concept dealing with relationships between sellers and buyers." This can be interpreted as taking an extreme 
dominant and most effective position in a business relationship, which would be monopoly. It best describes the shape of the final level. However, we should be aware as to what brings a monopoly phenomenon. Monopoly can be caused from many different reasons; it could be from resource ownership or from statutory or product differentiation or so. US films dominated the world market, whereas its competitors did not have enough capacity or enough capital to produce films with quality from the after effects of the world wars. The monopoly in this level describes that a nation's film industry can wield power based upon its leading edge technology or entirely different creativity.

\section{Result}

In accordance with the historical analysis above, a maturity framework is developed with features of condition and strategy in each level. As mentioned above, five different levels are set by priority; from an introduction to an ideal form. In addition, each level is divided into two stages based on the attributes of industry; both 'first entering' and 'returning' conditions are considered in each level. In each level of the framework, the features of conditions are described and possible strategies are suggested in order to move forward to the next level. Table 2 shows the final maturity framework output for the commercial culture.

Table 2. Maturity framework for commercial culture in free economy system

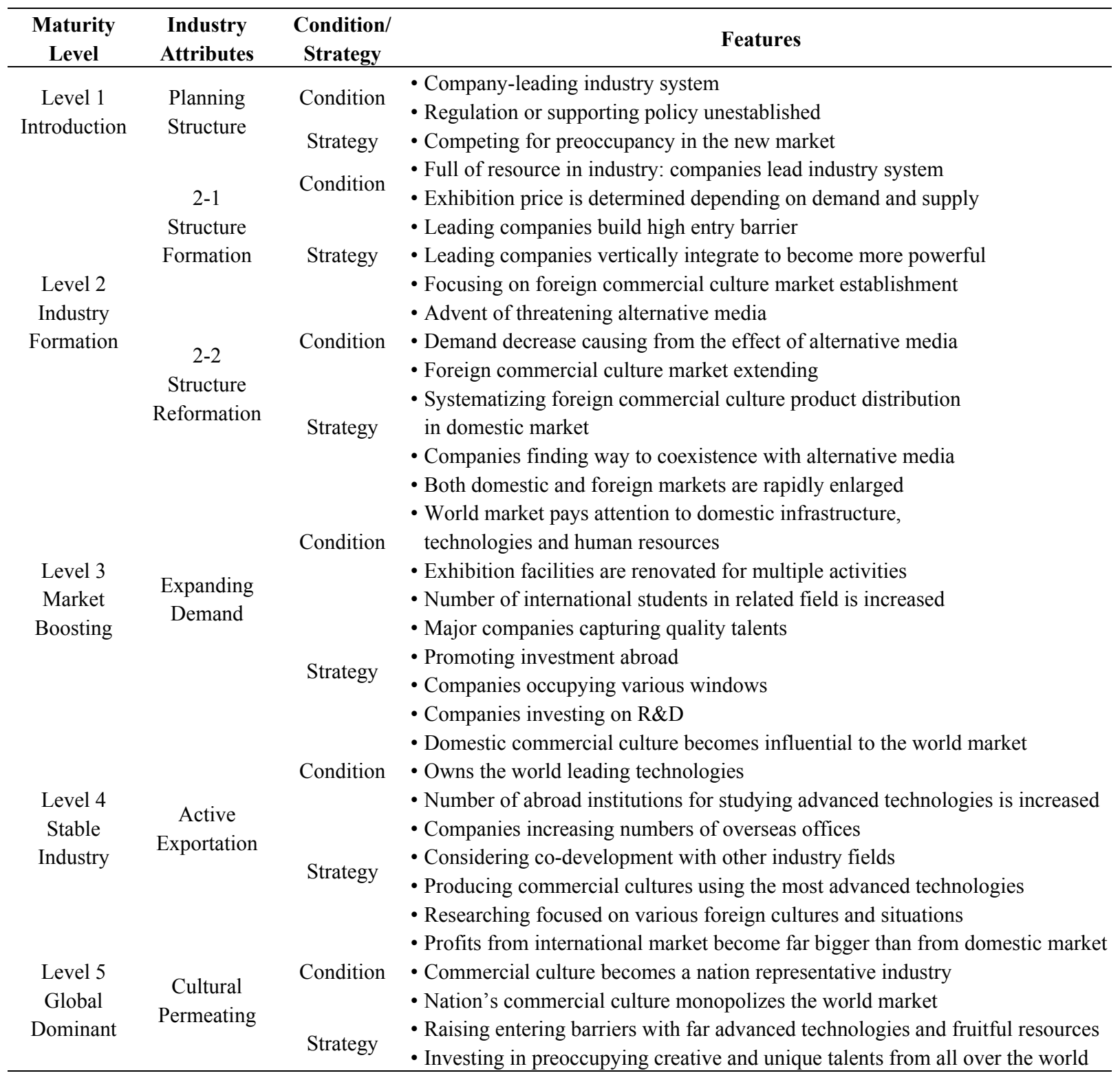




\section{Conclusion}

From historical data, it has been found that culture industry has been continuously developing toward the stable condition. It is a very similar idea with the notion, that the highest level of quality, which most general maturity models have suggested, was optimization. The construction of the framework has implications for making possible to assume the commercial quality of products in a certain period. To draw a maturity framework for commercial culture, the film industry was analyzed, because film is a representative commercial culture, which has already formed as an industry from the beginning. This paper, however, is limited observations in the film industry; the next step will be to see other commercial cultures, such as music and games. It will be also considerable to find more examples from other countries in order to increase the reliability. For the further study, framework is planned for expansion in order to establish a maturity model for commercial culture.

\section{References}

Ahern, D. M., Clouse, A., \& Turner, R. (2004). CMMI distilled: a practical introduction to integrated process improvement (2nd ed.). Boston; London: Addison-Wesley.

Fisher, D. M. (2004). The Business Process Maturity Model A Practical Approach for Identifying Opportunities for Optimization. Business Process Trends. Retrieved from http://www.bptrends.com/publicationfiles/1004\%20ART\%20BP\%20Maturity\%20Model\%20-\%20Fisher.pdf

Godfrey, S. (2004). What is CMMI? Retrieved from htttp://software.gsfc.nasa.gov/docs/What\%20is\%20CMMI. ppt

Harmon, P. (2004). Evaluating an Organization's Business Process Maturity. Business Process Trends. Retrieved from http://www.bptrends.com/publicationfiles/03-04\%20NL\%20Eval\%20BP\%20Maturity\%20-\%20Harm on.pdf

Hill, J. (2013). Business Process Management Maturity model. Gartner. Retrieved from http://www.pega.com/sites/default/files/private/Advancing-Beyond-the-Early-Stages.pdf

Hite, R. C. (2010). Organizational Transformation: A Framework for Assessing and Improving Enterprise Architecture Management (Version 2.0). U.S. Government Accountability Office. Retrieved from http://www.gao.gov/assets/80/77237.html

Jenkins, H. (2008). Convergence Culture. NYU Press, New York.

Kim, P., Yoon, H., \& Jang, G. (2007). Culture Content Industrial Theory. Communication Books, Korea.

McAllister, M. (2003). Is commercial culture popular culture?: A question for popular communication scholars. Journal of Popular Culture, 1, 41-49. http://php.scripts.psu.edu/users/m/p/mpm15/CommercialCulture.pdf

Nightingale, J. (1978). On the definition of 'industry' and 'market'. The Journal of Industrial Economics, 27(1), 31-41. http://www.jstor.org/stable/2098116

Paulk, M., Curtis, B., Chrissis, M. B., \& Webber, C. (1993). Capability Maturity Model for Software, Version 1.1 Software Engineering Institute. Carnegie Mellon University, Pennsylvania, USA.

Ramanujan, S., \& Kesh, S. (2004). Comparion of Knowledge Management and CMM/CMMI Implementation, Journal of American Academy of Business, 4(1), 271-277. http://www.umsl.edu/ lacity/cmm2.pdf

Seo, J. (2009). All about Hollywood: History, System, Narrative, and Genre. Theory and Practice, Korea.

Shin, K. (2013). Hollywood Cinema. Communication Books, Korea.

Song, N. (2007). Post Hollywood. Communication Books, Korea.

Stephen, N. (2008). Green IT: beyond the data center- How it can contribute to the environmental agenda across and beyond the business. Accenture. Retrieved from http://www.accenture.com/us-en/Pages/insighttechnology-consulting-green-it-beyond-data-center.aspx

Thomson, K., \& Bordwell, D. (2009). Film History: an Introduction (3rd ed.). McGraw-Hill, New York, USA.

\section{Copyrights}

Copyright for this article is retained by the author(s), with first publication rights granted to the journal.

This is an open-access article distributed under the terms and conditions of the Creative Commons Attribution license (http://creativecommons.org/licenses/by/3.0/). 